\title{
Budget Policy in Uzbekistan: Practical and Strategic Directions
}

\author{
Rakhmonov Dilshodjon and Sherov Anvar Umarovich
}

\begin{abstract}
The theoretical foundations of budget policymaking are researched in this article. Elements of budget policy were identified and evaluated taking into account its specific features. The trends of budget policy implementation are shown. The conclusions are formulated due to the research.
\end{abstract}

Index Terms - budget, budget policy, income distribution, finance, budget policy models.

\section{INTRODUCTION}

President of the Republic of Uzbekistan in his address to the Chambers of the Oliy Majlis (Parliament) of the Republic of Uzbekistan dated December 28, 2018 noted that it is necessary to improve the system of effective use of budgetary funds. Any program or project that is funded from the budget should have indicators of quality and quantity that are outcome-oriented. This reflects the urgency of the tasks facing the budgetary policy.

The need for the efficient use of budget funds for the implementation of budgetary policy is determined. It should be noted that this is achieved through clarifying priorities for budget expenditures. In this process, budgetary policy formation occurs with the transition of budget expenditures from the public to the private sector based on market relations.

According to the Budget Code of the Republic of Uzbekistan budget expenditure trends are identified and fundamentals of budget policy are defined. According to Article 69 of this Code, the expenditure part of the State Budget shall include:

- $\quad$ Expenditures on the social sphere and social support of the population;

- Expenditures of state support to NGOs and other civil society institutions;

- $\quad$ Expenditures on economy;

- $\quad$ Expenditures of financing centralized investments;

- Expenditures for maintenance Government and administration, Ministry of justice and public prosecution;

- $\quad$ Expenditures for maintaining courts;

- Expenditures for maintenance of self-government authorities;

- Other expenditures.

Although these expenditure directions are financed from the budget funds, we believe that budgetary priorities will be evident as the amount of funding allocated to this spheres changes over the years.

For example, the trends in spending on education, health care, science, sports, and material support in the social expenditure and social security expenditures are closely linked to budgetary policies in this direction.

In particular, if the share of the state budget expenditure on science in relation to GDP was $0.3 \%$ on average till 2017 , it is worth noting that by 2018 the budget policy changed. According to the Decree of the President of the Republic of Uzbekistan dated September 21, 2018 "On approval of the Strategy of Innovative Development of the Republic of Uzbekistan in 2019-2021", the expenditure on science sector will be increased by $0.8 \%$ to GDP. Increased budget expenditures in this area reflect government support for science and, consequently, innovative activities.

The goal is to create conditions that will allow Uzbekistan to enter the top 50 of the global innovation rating by 2030 .

In my opinion, fiscal policy formation is related to the tendency of budget expenditures to change for a particular sector. In particular, the privatization of enterprises with a state share of economic costs will result in a reduction in budget subsidies.

The deepening of market relations in the country will lead to radical changes in budget policy. In particular, some of the tasks that the government has to provide are paid for to the public, resulting in a change in budget expenditure.

On the contrary, with the development of other factors, there is an expansion of responsibilities on the state. As a result, there is an increase in budget spending. For example, as the environmental situation changes, the government will need to increase its budget expenditure to address environmental causes and reduce their causes. For example, the Decree of the President of the Republic of Uzbekistan dated January 18, 2017 "On the State Program for Development of the Aral Sea Region for 2017-2021" established Aral Sea Rescue Fund. In line with the Fund's revenues, targeted funds of the State Budget of the Republic of Uzbekistan, including centralized investments, are defined..

\section{LITERATURE REVIEW}

In my view, the accelerated market relations will result not only in the reduction of public duties and the provision of these services to the population on a paid basis, but also there will be in need to fulfill the new tasks of the state. As a result, there is a tendency for changes in the fiscal policy to be specific. This requires the formulation of a budget policy, depending on budget expenditures.

This cyclical change in budget policy requires additional 
funding from the budget. This is due to the discrepancy between budget revenues and expenditures. In turn, it emphasizes the need to pay attention to the principles of budget deficit management in fiscal policy.

In this regard, U. Burkhanov (2002) conducted a research aimed at the emergence and overcoming of budget deficit. He noted that the budget deficit as a cost factor, the following types of expenditures highlight the following factors in reducing the deficit:

abolition of subsidies for inefficient state enterprises in the energy, agriculture, industry, transport and communications spheres;

reducing subsidies to state-owned enterprises through accelerating the privatization process, and strengthening revenues by selling state-owned assets;

the high expenditures in health care sphere, even in developed countries;

the need for adequate funding indicators for education in line with demographic development;

A reduction in the expenditure of social protection by reducing the share of the low-income population;

the need to reduce the share of centralized investments.

In general, starting from 2018, a number of reforms are being implemented to cover the state budget deficit and expand sources of external financing. In particular, the Decree of the President of the Republic of Uzbekistan dated July 21, 2018 № PP-3877 "On additional measures to diversify sources of external financing" was adopted. According to this decision it became necessary to obtain sovereign credit rating of the country. Obtaining a sovereign credit rating will result in a significant public debt formation.

This will reduce the short-term financial burden on the budget. However, the attracted foreign funds will be budgeted in the long run.

Besides I think that the adoption of the Decree of the Cabinet of Ministers of the Republic of Uzbekistan dated December 14, 2018 No. 1016 "On measures to organize the circulation of state treasury obligations and bonds of the Republic of Uzbekistan" will have an impact on budgetary changes. According to the resolution, the proceeds from the placement of government bonds will be transferred to the State Budget of the Republic of Uzbekistan and measures aimed at covering the deficit of the State budget and socioeconomic development of the country, as well as in the framework of approved budget expenditure parameters of the Republic of Uzbekistan implementation of large investment projects as determined by the decisions of the President of the Republic of Uzbekistan.

In my opinion, the budget deficit, which is considered to be a macroeconomic indicator in budget policy, is important. The reason for this is that there is a negative balance between income and expenditure when attracting investment to the budget.

In general, research has been done on specific areas of budget expenditures and their features. For example, Raimimberdieva considers the following points on health care financing (Rayimberdieva, 2001):

clear delineation of health care services by public and private sectors;

Determining compliance among health care financing sources; strengthening of medical competition, introduction of more efficient mechanisms for allocation and use of budgetary funds;

Increasing the interest of medical personnel in the end result of their activities.

I think that the correlation between public and private sector financing in health care is dictated by the need to prevent, firstly, the preservation of the social nature of health services and, secondly, the need to prevent it from becoming commercial nature. On the other hand, it further enhances the possibility of budgeting. Some aspects of this issue are reflected in the scientific conclusions of the research above.

Also, Nabiev (2005) conducted research on investment in the education system. In particular, it is emphasized that education, science, and entrepreneurship can achieve better results as a result of the interoperability of each other.

Another researcher from Uzbekistan, Dustmukhammad (2012), has done research on public education funding. According to the results of his research following recommendations are made :

The organization of effective implementation of the costs of the public education system depends first and foremost on the absolute and relative levels of indicators that expenditures should be covered and calculated.

The best way to spend per pupil on the average is to pay for the education system, rather than the method of budgeting the costs of maintaining general education institutions.

The number of pre-schools, secondary schools and pupils in Uzbekistan has a tendency to decrease year by year. On the contrary, it is noted that the number of academic lyceums in the country is on the rise.

It should be noted that the role of budgetary funds in the education system has always been flawless, In all developed and developing countries, the budget expenditure in this area is a separate line item. In particular, the first ideas for the development of public-private partnerships in education are reflected in research on investment in education. The role of this issue in investing in education is certainly important. An important step in this regard Decree of the President of the Republic of Uzbekistan dated October 20, 2018 No. PP-3980 "On Priority Measures to Establish the Legal and Institutional Framework for the Development of Public-Private Partnership" was the adopted. According to the decree, the Agency for Public Private Partnership Development established under the Ministry of Finance of the Republic of Uzbekistan. This will allow the financing of some activities of budgetary institutions with the efficient use of private funds.

Another researcher U. Pardaev (2018) provides conclusions on improving the methodology for forecasting the state budget in his research. Although the present study aims to study the forecasting of the state budget, the emphasis is on the fact that the proposals focused on budget revenues and elaborations also cover the optimization of tax revenues.

Another scholar from Uzbekistan, D.Rakhmonov (2018), also commented on budget policy trends. In particular, it is noted that education, health care and science are the priority areas of budgeting for the social sphere. It is important to give financial independence to higher education institutions and thus to use the rankings of higher education institutions in determining their amount of tuition fee. Also, it was identified 
and assessed the possibility of introducing compulsory health insurance in the health sector, which covered the population through the insurance mechanism. At the same time, it emphasizes the need to implement reforms aimed at developing the category of human capital in the social sector.

It should be noted that budget allocations and their specifics have been studied as separate objects in the research. However, the lack of clarity on the general directions of budgetary policy makes it possible to reiterate the relevance of this study.

According to the leading scholar of Uzbekistan T.Malikov (2012) noted that "Under the current conditions the state budget represents part of social (production) relations, accumulating a relatively large part of the national GDP, the national income, and introducing it into various spheres of social development (economy, education, health, science, culture, social security, governance, defense, etc.) are important means of distribution ".

In my opinion, T.Malikov made his conclusions on all directions of budgetary policy. According to him, the budgetary policy would serve as a means of distributing a portion of the national income generated in the country, which would have been even more important given the budget redistribution task.

\section{RESEARCH METHODOLOGY}

The study provides a systematic analysis of scientific works aimed at identifying the types of budget policy. Also, information analysis is carried out on the basis of budget policy.

\section{ANALYSIS AND RESULTS}

It is noted that the provision of basic government information at the national level is funded by the budget both in accordance with international experience and in accordance with the Constitution of Uzbekistan, and as a result, the free education of the population will be provided. In particular, this shows a high share of budget expenditures on education.

Due to the increasing budget spending on education, the coverage of education increased by 0.7 percentage points in 2017 compared to 2005. As a result, it is worth noting that amount of the population with higher education has grown. In particular, it is estimated that they increased by 5.4 percentage points during the period under review (see Table 1).

Table 1. The percentage of population aged 25 years and older in Uzbekistan in 2005-2017

\begin{tabular}{|c|c|c|}
\hline Years & Literacy & $\begin{array}{l}\text { Including higher education higher and } \\
\text { other }\end{array}$ \\
\hline 2005 & 99,3 & 10,8 \\
\hline 2010 & 99,8 & 13,5 \\
\hline 2017 & 100,0 & 16,2 \\
\hline
\end{tabular}

Welfare of the Republic of Uzbekistan, 2018

The upward trend in budget expenditures in this area can be seen in the results of ongoing reforms to predict increases in the years to come. For example, if 62900 students graduated from higher education institutions in 2017 (Statistics Committee, 2018), it should be noted that the enrollment in higher education institutions in the 2018/2019 academic year was 69,200 (Presidential Decision, 2018). These figures show that budget expenditure may be required to increase funding for these activities. It is also indicative of the fact that the regional branches of several higher education institutions have been set up in the 2018/2019 academic year.

However, we can observe that there is a tendency towards a decline in the share of social sector expenditures in relation to the state budget from the Decree of the President of the Republic of Uzbekistan No. PP-4086 of December 26, 2018, approved budget parameters for 2019, these means that there is a need to increase the share of extra-budgetary funds. According to the decree, expenditures on social sphere will make up 54844.3 trillion. sums, and their share is $51 \%$. However, in 2018 this figure was $56 \%$ of the state budget (according to the Ministry of Finance).

Another factor is that the share of expenditures on services in the structure of the population's expenses is increasing. In particular, this figure was $12.8 \%$ of total expenditures in 2000 , and in 2017 it raised to $20.0 \%$. This is explained by the fact that the conditions for the introduction of paid tariffs in the provision of social services.

In my opinion, it is necessary to take into account all the elements of market relations in the formulation of budgetary policy. Therefore, it should be noted that the share of expenditures in the social sector, which has a dominant share in the structure of budget expenditures until 2018, is significantly reduced from 2019.

Also, the funds are allocated in the direction of "Credit line for the joint implementation of the program of individual housing construction in rural areas" in the structure of budget expenditures. Funding for these activities will be provided in the social expenditure structure. For example, if these expenditures were $5.5 \%$ in $2016,0.5 \%$ in 2017 and $0.7 \%$ in 2018 , then the level of fiscal policy in this area can be noted.

It is closely related to the implementation of individual housing projects in rural areas during 2016 and beyond. Starting in 2017, construction of new low-cost projects was planned. In particular, the adoption of the Decree of the President of the Republic of Uzbekistan dated October 21, 2016 No. PP-2639 "On the program of low-cost housing construction in the countryside in 2017-2021" contributed to the renewal of the reforms.

It should be noted that the implementation of budgetary policy is explained not only by the amount of funds, but also on the new stage of reforms. Therefore, $i$ think that it is advisable to follow the elements of the budget in the formulation of budget expenditure trends.

In this regard, Professor Z. Zaynalov (2014) states: "There is a growing need for access to information on all expenditure trends across the country, including spending in districts, as well as improving services for public education and public health financing".

The Recommendation put forward by Zaynalov focuses on the expenditure on education and health care in the implementation of budget expenditures. He also emphasizes the importance of efficiency in budget spending.

Adoption of the Strategy of actions for further development of the Republic of Uzbekistan adopted on February 7, 2017, reflects the fact that the budget system maintains socially oriented market economy relations and 
reflects the social orientation of budget expenditures and improvement of inter-budgetary relations in accordance with this Decree.

According to the strategy of Actions, Decree of the President of the Republic of Uzbekistan № PP-3917 dated August 22, 2018 "On measures to ensure the openness of budget information and active participation of citizens in the budget process", transparency is a key factor in budget policy. While the social orientation of budget expenditures is the primary factor in budget policy, transparency as a second factor is an important area of budget policy. It is noteworthy that the introduction of a mechanism for the formation and implementation of the state budget, which envisages at least $10 \%$ of additional sources of district (city) budgets to the public events.

Besides, the launch of the Open Budget portal is one of the key factors in the transparency reforms. The Budget Transparency Study is expected to take into account the following documents (Citizens Budget, 2018):

- The preliminary draft budget;

- draft budget;

- adopted budget;

- budget for citizens;

- current report;

- semi-annual report;

- Audit report.

At every stage of the aforementioned budget processes, active involvement of citizens, including public oversight, is required. In particular, the provision of transparency in budgeting in the regions at the rate of $10 \%$ of the total expenditure on public opinion contributes to transparency.
- clarity;

- $\quad$ sociality;

- $\quad$ Efficiency.

The principle of purposefulness in the above mentioned elements of budgetary policy implies the importance of ensuring efficiency in the use of budgetary funds, which are of the people's money. In addition to social expenditure, which represents a significant part of the budget expenditure, other social budgeting implies that it will eventually produce social benefits..

\section{REFERENCES}

[1] Address by the President of the Republic of Uzbekistan Sh.Mirziyeev to Chambers of Oliy Majlis. 2018 year.

[2] Decree of the President of the Republic of Uzbekistan dated June 4, 2018 "On admission to higher educational institutions of the Republic of Uzbekistan for the 2018/2019 academic year"

[3] Budget Code of the Republic of Uzbekistan. December 26, 2013.

[4] Rayimberdieva O.R. Organization of financing of health care facilities: abstract ... Ph.D: - Tashkent: BFA, p.22, 2001

[5] Burkhanov U.A. Factors of State Budget Deficit and Reduction in Economic Liberalization: abstract ... Ph.D: - Tashkent: BFA, p.22, 2002 .

[6] Nabiev D.H. Issues of financing investment in education (on the example of the system of secondary special and vocational education in Uzbekistan): abstract ... Ph.D: - Tashkent: BFA, p.22, 2005.

[7] Dustmukhammad X.U. Ways to organize effective financing of public education abstract ... Ph.D: - Tashkent: BFA, p.22, 2012.

[8] Pardaev U.U. Improvement of the methodology of state budget forecasting: abstract ... Ph.D: - Tashkent: TIF, p.58, 2018.

[9] Zaynalov JR, Alieva S.S. Ways of developing services for maintaining the efficiency of the treasury system: Scientific e-journal Economics and Innovative Technologies, vol.3(2). May-June 2014.

[10] Ambaryan Development of a public procurement management support system using conceptual modeling, XXI century: results of the past and problems of the present plus, vol. 6(28). Pp. 281-286. 2015.

\section{CONCLUSIONS}

Based on the research, it is possible to note the implementation of budget policy in the following areas:

Use of systematic analysis elements in the planning of social expenditures, such as: preventing passive growth of average life expectancy as a positive result in health care. In other words, the same is true of their contribution to the growth of gross income as life expectancy increases Then life expectancy becomes more active. In this case, it is necessary to standardize the social and financial conditions for the education of people.

- reduction of the state's share of the economy in order to prevent the increase in budget expenditures at the expense of budgetary expenses, and gradually reducing the financing centralized investments from the state budget. In this, it should be prioritizing public-private partnerships.

- $\quad$ Priority of budget policy in the implementation of reforms aimed at eliminating the environmental consequences of modernization of the economy. At the same time, strengthening the regulation of the processes that complicate the environmental situation through the budgetary mechanism;

A number of elements of budget policy implementation include:

- purposefulness;

- $\quad$ transparency; 